\title{
Gambaran Karakteristik Ibu yang Melakukan Inisiasi Menyusu Dini di PMB Anik Mupidah,Amd.Keb Desa Gelang Kulon Kecamatan Sampung Kabupaten Ponorogo
}

\author{
Qoni'atun Nurnaini ${ }^{1}$, Yulia Nur Khayati ${ }^{2}$ \\ ${ }^{1}$ Program Studi Kebidanan Program Sarjana, ${ }^{2}$ Program Studi D3 Kebidanan, \\ Universitas Ngudi Waluyo \\ Email: qoni.nuraini97@gmail.com,yulia.farras@gmail.com
}

\begin{abstract}
ABSTRAK
Salah satu upaya untuk meningkatkan angka keberhasilan pemberian ASI adalah dengan pelaksanaan program pemberian ASI dini (IMD) pada bayi baru lahir kepada ibunya. Manfaat menyusui pada bayi usia dini antara lain adalah mengurangi kematian bayi akibat hipotermia, bayi akan mendapatkan kolostrum yang kaya antibodi yang diperlukan untuk pertumbuhan usus dan melawan infeksi. Sementara bagi para ibu hubungan cinta ibu dan bayi sangat baik, akan merangsang pelepasan oksitosin., mengurangi resiko perdarahan dan mempercepat pelepasan plasenta. Di Kabupaten Ponorogo pada tahun 2019 sebesar 88,72\% yang melakukan IMD. Ibu yang bersalin di tempat Bidan Anik banyak ibu yang melakukan IMD pada bayi baru lahir. Tujuan penelitian ini untuk mengetahui bagaimana gambaran karakteristik ibu yang melakukan IMD di PMB Anik Mupidah,Amd.Keb. Penelitian menggunakan desain penelitian deskriptif dengan pendekatan retrospektif (backward looking). Populasi yaitu seluruh ibu bersalin yang melakukan IMD di PMB Anik Mupidah,Amd.Keb dari bulan JanuariNovember 2020. Sampel sebanyak 39 ibu bersalin dengan teknik sampel menggunakan total sampling. Pengolahan data dengan menggunakan distribusi frekuensi. Hasil penelitian menunjukkan dari $39 \mathrm{ibu}$ bersalin yang melakukan IMD sebagian besar umur20-35 tahun $31(79,5 \%)$, multipara 23 (59,0\%), tidak bekerja $21(53,8 \%)$, menengah/SMA $19(48,7 \%)$.
\end{abstract}

\section{Kata Kunci : Karakteristik, Inisiasi Menyusu Dini}

\section{ABSTRACT}

Description of the Characteristics of Mothers who Initiate Early Breastfeeding at PMB Anik Mupidah, Amd.Keb, Bracelet Kulon Village, Sampung District, Ponorogo Regency

One of the efforts to increase the success rate of breastfeeding is by implementing an early breastfeeding program (IMD) for newborns to their mothers. The benefits of breastfeeding in early childhood include: reducing infant mortality due to hypothermia, the baby will get colostrum which is rich in antibodies needed for intestinal growth and fighting infection. Meanwhile for mothers, the love relationship between mother and baby is very good, it will stimulate the release of oxytocin, reduce the risk of bleeding and accelerate the release of the placenta. In Ponorogo Regency in 2019, 88.72\% carried out IMD. Many mothers who give birth at midwife Anik's place do IMD on their newborns. The purpose of this study was to determine the description of the characteristics of mothers who perform IMD at

Gambaran Karakteristik Ibu... Qoni'atun Nurnaini, Yulia Nur Khayati Journal of Holistics and Health Sciences Vol. 3, No. 2 September 2021 
PMB Anik Mupidah, Amd.Keb. This type of research is a descriptive correlative study with a retrospective time approach (backward looking). The population was all mothers who gave birth to IMD at PMB Anik Mupidah, Amd.Keb from January to November 2020. A sample of 39 mothers gave birth using a total sampling technique with frequency distribution data processing. The results showed that from 39 mothers who gave birth to IMD, most of them were aged 20 -35 years 31 (79.5\%), multiparous 23 (59.0\%), not working 21 (53.8\%), middle / high school 19 (48, 7\%).

\section{Keywords: Characteristics, Early Initiation of Breastfeeding}

\section{PENDAHULUAN}

Salah satu upaya untuk
meningkatkan pemberian ASI adalah pelaksanaan Inisiasi Menyusu Dini (IMD) oleh bayi baru lahir pada ibunya. IMD akan sangat membantu dalam keberlangsungan pemberian ASI eksklusif dan lama menyusui. Dengan demikian, bayi akan terpenuhi kebutuhannya hingga usia 2 tahun, dan mencegah anak kurang gizi (Zakiah, 2018).

Menurut Riset Kesehatan Dasar (Riskesdas) Tahun 2013, persentase tertinggi proses mulai menyusu pada anak umur 0-23 bulan adalah pada 1-6 jam (35,2\%). Proses mulai menyusu pada satu jam pertama setelah lahir/IMD hanya $34,5 \%$. IMD mengalami peningkatan pada tahun 2018. Berdasarkan hasil Riskesdas tahun 2018, proporsi IMD pada anak umur 0-23 bulan adalah 58,2\%. Dari proporsi ini, yang melakukan IMD $\geq$ 1 jam hanya 15,9\% (Infodatin ASI, 2018).

Secara nasional tahun 2019 persentase bayi baru lahir yang mendapat IMD yaitu sebesar $75,58 \%$. Angka ini telah melampaui target Renstra tahun 2019 yaitu sebesar $50,0 \%$. Berdasarkan Peraturan Pemerintah Nomor 33 Tahun 2012 tentang Pemberian Air Susu Ibu Eksklusif adalah ASI yang diberikan kepada bayi sejak dilahirkan selama enam bulan, tanpa menambahkan dan/atau mengganti dengan makanan atau minuman lain (kecuali obat, vitamin, dan mineral). Pada provinsi Jawa Timur pada tahun 2019 presentase bayi baru lahir yang mendapat IMD pada umur $<1$ jam sebesar $84,9 \%$. Sedangkan pada kabupaten Ponorogo sendiri pada tahun 2019 sebesar 88,72\% yang melakukan IMD pada bayi baru lahir umur kurang dari satu jam (Profil Kesehatan Indonesia 2019, BPS Provinsi Jawa Timur 2019).

Manfat inisiasi menyusu dini pada bayi antara lain; menurunkan angka kematian bayi karena hipotermia, bayi mendapatkan kolostrum yang kaya akan antibodi penting untuk pertumbuhan usus dan ketahanan terhadap infeksi, menghangatkan bayi melalui dada ibu dengan suhu yang tepat. Sedangkan manfaat bagi ibu antara lain; jalinan kasih antara ibu dan bayi baik sebab bayi siaga dalam 1-2 jam pertama. Sentuhan, jilatan, usapan pada puting susu ibu akan merangsang pengeluaran hormon oksitosin. Mengurangi resiko perdarahan dan mempercepat pelepasan plasenta (Aprilia Y, 2010).

Menurut Khoniasari, 2015 ada beberapa faktor-faktor yang mempengaruhi pelaksanaan IMD diantaranya adalah paritas, pengetahuan ibu, dukungan keluarga, dan tenaga kesehatan yang belum sepenuhnya mendukung program 
peningkatan penggunaan ASI. Dan Khasanah, 2013 mengatakan sebenarnya IMD sangat mudah melaksanakannya. Hanya ada beberapa faktor yang mendukung keberhasilannya, yaitu tergantung dari kesiapan fisik dan psikologi ibu yang sudah harus dipersiapakan dari awal kehamilannya, serta dukungan keluarga. Konseling dalam pemberian informasi mengenasi inisiasi menyusu dini bisa diberikan selama pemeriksaan. Adapun pada penelitian sebelumnya yang dilakukan oleh Indah (2012) dengan judul "Gambaran karkteristik ibu yang melakukan Inisiasi Menyusu Dini di BPS S Kulon Progo". Dari hasil penelitian ibu-ibu yang memiliki karakteristik yang saling mendukung keberhasilan ibu dalam melakukan Inisiasi Menyusu Dini. Gambaran karakteristik ibu yang melakukan IMD berdasarkan usia ibu terdapat $80,49 \%$ ibu usia produktif yaitu usia 20-30, dan karakteristik Paritas sebesar $83,36 \%$ pada ibu dengan jumlah anak 1 atau Primi, 97,56\% ibu melakukan IMD pada usia kehamilan aterm, 78,05\% ibu dengan pendidikan menengah (SMP, SMA) dan ibu yang tidak bekerja yang melakukan IMD sebesar 85,37\%. (Khoiniasari 2015, Khasanah 2013 dan Indah 2012).

Inisiasi Menyusu Dini merupakan salah satu cara untuk menurunkan angka kematian bayi. Selain menurunkan angka kematian bayi, IMD juga dapat membantu ibu dalam menyusui yang merupakan alternatif terbaik untuk mencegah pemeberian makanan/minuman prelaktal. IMD mempunyai pengaruh sangat nyata terhadap pelaksanaan ASI Eksklusif. Di PMB Anik Mupidah,Amd.keb ada 39 ibu bersalin yang melakukan Inisiasi Menyusu Dini dalam waktu satu tahun, tahun 2020 dari JanuariNovember. Bidan Anik mengatakan ibu yang bersalin di tempatnya kebanyakan dilakukan IMD pada bayi baru lahir. Dari latar belakang tersebut peneliti ingin mengetahui bagaimana pelaksanaan IMD di PMB tersebut, maka peneliti akan melakukan penelitian bagaimana gambaran karakteristik ibu yang melakukan IMD di PMB Anik Mupidah,Amd.Keb.

\section{METODE PENELITIAN}

Jenis penelitian ini merupakan penelitian deskriptif dengan desain penelitian yang digunakan adalah menggunakan pendekatan waktu retrospektif (backward looking). Waktu penelitian dilakukan mulai bulan November 2020 sampai Januari 2021. Penelitian in dilakukan di PMB Anik Mupidah,Amd.Keb Desa Gelang Kulon Kecamatan Sampung, Ponorogo. Populasi dari penelitian ini adalah ibu yang melahirkan dan melakukan IMD di PMB Anik Mupidah,Amd.Keb sebanyak 39 ibu bersalin. Sampel penelitian ini adalah 39 ibu bersalin dengan teknik total sampling. Pengambilan data menggunakan data sekunder dari data rekam medis buku register persalinan di PMB Anik Mupidah, Amd.Keb. Dan analisis menggunakan analisis univariat.

\section{HASIL DAN PEMBAHASAN}

\section{HASIL}


Tabel 1 Distribusi Frekuensi karakteristik Ibu yang Melakukan Inisiasi Menyusu Dini di PMB Anik Mupidah,Amd.Keb.

\begin{tabular}{llcc}
\hline Karakteristik & & Frekuensi & Presentase (\%) \\
\hline Umur & $<20$ tahun & 5 & 12.8 \\
& 20-35 tahun & 31 & 79.5 \\
& $>$ 35 tahun & 3 & 7.7 \\
\hline Paritas & Primipara & 16 & 41.0 \\
& Multipara & 23 & 59.0 \\
& Grandemultipara & - & - \\
\hline Pekerjaan & Bekerja & 18 & 46.2 \\
& Tidak bekerja & 21 & 53.8 \\
\hline \multirow{2}{*}{ Pendidikan } & Dasar (SD,SMP) & 10 & 25.6 \\
& Menengah (SMA) & 19 & 48.7 \\
& Tinggi (PT) & 10 & 25.6 \\
\hline
\end{tabular}

Berdasarkan penelitian karakteristik ibu yang melakukan IMD di PMB Anik Mupidah, Amd.Keb diketahui usia ibu yang melakukan Inisiasi Menyusu Dini sebagian besar usia 20-35 tahun sebanyak 31 orang $(79,5 \%)$. Paritas ibu yang melakukan IMD sebagian besar pada multipara sebanyak 23 orang $(59,0 \%)$. Status pekerjaan ibu yang melakukan IMD sebagian besar ibu yang tidak bekerja 21 orang $(53,8 \%)$. Tingkat pendidikan ibu yang melakukan IMD sebagian besar Menengah/SMA sebanyak 19 orang $(48,7 \%)$.

\section{PEMBAHASAN}

\section{Usia}

Berdasarkan hasil analisis dapat diketahui bahwa ibu yang melakukan Inisiasi Menyusu Dini di PMB Anik Mupidah, Amd.Keb pada usia $<20$ tahun sebanyak 5 orang (12,8\%). Menurut Hidajati (2012), dikatakan bahwa umur $<20$ tahun masih belum matang secara fisik, mental maupun psikologi dalam melakukan inisiasi menyusu secara dini pada bayinya.

Ibu usia 20-35 tahun yang melakukan IMD lebih banyak yaitu 79,5\% karena pada usia tersebut merupakan usia yang stabil mampu memberikan sikap dan menerima informasi dengan baik. Menurut Soetjiningsih (2011) dukungan atau sikap positif dari pasangan dan keluarga akan memberikan kekuatan tersendiri bagi ibu. Dukungan petugas kesehatan sangat penting dalam kelangsungan IMD karena dapat meningkatkan rasa percaya diri ibu dan berperan sebagai penyedia informasi yang diperlukan. Ibu umumnya mau, patuh dan menuruti nasehat petugas kesehatan, oleh karena itu petugas kesehatan diharapkan untuk memberikan informasi tentang waktu yang tepat untuk melakukan inisiasi menyusu secara dini (Roesli, 2009).

Ibu usia > 35 tahun sedikit yang melakukan IMD yaitu $7,7 \%$ karena pada usia tersebut merupakan diatas usia produktif, sehingga pada usia tersebut jarang ibu mengalami kehamilan. Selain itu pada usia 30 tahun terjadi proses degenerasi payudara mengenai ukuran dan kelenjar alveoli mengalami regresi, sehingga dengan proses tersebut payudara cenderung kurang menghasilkan air susu (Prakoso, 2002).

Sesuai dengan teori Prawirohardjo (2007) bahwa usia wanita yang dianggap optimal untuk 
kehamilan adalah 20-35 tahun. Usia wanita $<20$ tahun atau $>35$ tahun merupakan usia yang beresiko bagi wanita untuk hamil dan melahirkan. Sedangkan pada kehamilan dengan usia > 35 tahun mempunyai resiko buruk. Usia produktif untuk hamil, melahirkan dan melakukan Inisiasi Menyusu Dini pada usia 20-35 tahun.

Penelitian sebelumnya yang dilakukan oleh Dwi, dkk (2016) usia ibu yang melakukan Inisiasi Menyusu Dini terbanyak pada ibu usia $<35$ tahun. Sedangkan penelitian yang dilakukan Awaliyah,dkk (2017) didapatkan hasil terbanyak pada usia dewasa (26-35 tahun) sebesar 65,2\%. Hasil penelitian yang dilakukan oleh peneliti juga mendapatkan hasil yang serupa, terbanyak pada ibu dengan umur 20-35 tahun. Selain karena baiknya usia produktif pada wanita, pada usia tersebut ibu bisa mengambil sikap dan menerima informasi tentang insiasi menyusu dengan baik.

\section{Paritas}

Paritas ibu yang melakukan IMD sebagian besar pada multipara sebnayak 23 orang $(59,0 \%)$. Seorang ibu yang mengalami laktasi kedua dan seterusnya cenderung untuk lebih baik daripada yang pertama. Laktasi kedua yang dialami ibu berarti ibu telah memiliki pengalaman dalam menyusui anaknya. Berdasarkan teori menurut Perinasia (2004) dalam Hidajati (2012) dikatakan seorang ibu dengan bayi pertamanya mungkin akan mengalami masalah ketika menyusui hanya karena kurang pengetahuan cara menyusui yang benar maupun trauma dari pengalaman menyusui kurang baik yang dialami orang lain. Hal tersebut yang memungkinkan ibu ragu untuk melakukan inisiaisi menyusu secara dini kepada bayinya.
Menurut Prawirohardjo (2007) , paritas 2-3 adalah jumlah paling aman ditinjau dari sudut maternal. Paritas 1 dan paritas $>3$ mempunyai angka kematian maternal yang lebih tinggi. Lebih tinggi paritas, lebih tinggi kematian. Resiko pada paritas 1 dapat ditangani dengan asuhan obstetric lebih baik, sedangkan resiko pada paritas tinggi dapat dikurangi atau dicegah dengan keluarga berencana. Sedangkan paritas tinggi adalah tidak direncanakan. Jadi dari hasil yang didaptkan sesuai dengan teori yang menyatakan multipara lebih baik dari primipara atau grandemultipara karena resiko obstetric yang lebih tinggi berdampak pada kematian maternal.

Penelitian sebelumnya yang dilakukan oleh Dwi, dkk (2016) terdapat hasil terbanyak dari ibu yang melakukan Inisiasi Menyusu Dini pada ibu Multipara. Sedangkan penelitian yang dilakukan oleh Awaliyah,dkk tahun 2017 didapatkan hasil terbanyak pada kelompok paritas multipara sebesar $65,2 \%$.

Hal ini senada dengan hasil dari peneliti yaitu terbanyak pada kelompok paritas multipara 59,0\%. Seorang ibu yang sudah melahirkan lebih satu kali mungkin lebih banyak pengetahuan maupun pengalaman ibu tentang inisiasi menyusu secara dini.

\section{Pekerjaan}

Status pekerjaan ibu yang melakukan IMD hanya berselisih sedikit yaitu lebih besar pada ibu yang tidak bekerja sebanyak 21 orang $(53,8 \%)$. Sedangkan menurut Astuti, 2013 Pekerjaan adalah kegiatan rutin yang dilakukan oleh ibu baik didalam rumah maupun di luar rumah yang menghasilkan imbalan materi atau uang. Wanita yang bekerja kemungkinan besar lebih sering 
keluar rumah, dan lebih sering berinteraksi dengan orang lain, sehingga informasi yang diperoleh lebih banyak. Sehingga kemungkinan terpapar informasi tentang IMD semakin besar (Astuti, 2013).

Penelitian sebelumnya yang dilakukan Dwi, dkk (2016) terdapat hasil terbanyak ibu yang melakukan Inisiasi Menyusu Dini yaitu pada ibu yang tidak bekerja. Dan pada penelitian yang dilakukan oleh Awaliyah, dkk tahun 2017 didapatkan hasil pada ibu yang tidak bekerja sebesar $93,1 \%$.

\section{Pendidikan}

Tingkat pendidikan ibu yang melakukan IMD sebagian besar Menengah/SMA sebanyak 19 orang $(48,7 \%)$. Berdasarkan teori Notoatmodjo (2007) dikatakan pendidikan ada kaitannya dengan pengetahuan ibu menyusui dalam melakukan inisiasi menyusu dini, hal ini dihubungkan dengan tingkat pengetahuan ibu bahwa seseorang yang berpendidikan rendah akan mempunyai pengetahuan yang lebih rendah dibandingkan dengan pendidikan tinggi. Tingkat pendidikan seorang ibu yang rendah memungkinkan lambat dalam mengadopsi pengetahuan baru khususnya hal-hal yang berhubungan dengan pelaksanaan IMD. Menurut teori Nursalam(2016), semakin tinggi tingkat pendidikan seseorang, maka semakin mudah menerima informasi sehingga makin banyak pula pengetahuan yang dimiliki. Sebaliknya pendidikan yang kurang akan menghambat perkembangan sikap seseorang terhadap nilai-nilai yang baru diperkenalkan.

Penelitian sebelumnya yang dilakukan Dwi, dkk (2016) terdapat hasil terbanyak pada ibu dengan pendidikan tinggi. Sedngkan penelitian Awaliyah, dkk tahun 2017 hasil terbanyak pada ibu dengan pendidikan tinggi/high level education (High School, College) sebesar $81,4 \%$.

Pendidikan ibu berpengaruh terhadap ASI eksklusif dan IMD. Ibu yang berpendidikan tinggi akan lebih baik penerimaannya terhadap ASI eksklusif dan IMD serta lebih berupaya untuk mempraktikannya. Pendidikan akan berpengaruh pada seluruh aspek kehidupan manusia baik pikiran, perasaan maupun sikapnya. Semakin tinggi tingkat pendidikan semakin tinggi pula kemampuan dasar yang dimiliki seseorang, khususnya pemberian ASI. Tingkat pendidikan dapat mendasari sikap ibu dalam menyerap dan mengubah sistem informasi tentang ASI.

\section{SIMPULAN}

Kesimpulan yang dapat diperoleh dari penelitian ini yaitu: Ibu yang melakukan IMD di PMB Anik Mupidah, Amd.Keb sebagian besar usia 20-35 tahun (79,5\%) dan sebagian kecil berusia > 35 tahun $(7,7 \%)$. Paritas ibu yang melakukan IMD di PMB Anik Mupidah, Amd.Keb sebagian besar multipara $(59,0 \%)$ dan sebagian kecil pada primipara $(41,0 \%)$. Status pekerjaan ibu yang melakukan IMD di PMB Anik Mupidah, Amd.Keb sebagian besar tidak bekerja $(53,8 \%)$ dan sebagian kecil bekerja (46,2\%). Tingkat pendidikan ibu yang melakukan IMD di PMB Anik Mupidah, Amd.Keb sebagian besar pada tingkat Menengah/SMA $(48,7 \%)$ dan sebagian kecil pada Dasar (SD,SMP) sebesar 25,6\%.

\section{DAFTAR PUSTAKA}


Aprillia S, Yesie. (2010). Hipnostetri, Gagas Media :Jakarta

Awaliyah, Imami, Hayuni. (2017). Breastfeeding selfefficacy as a dominant factor affecting maternal breastfeeding satisfaction. https://doi.org/10.1186/s 12912-019-0359-6

Azmi, Zakiyah. (2018). Faktor Faktor Yang Mempengaruhi

Pelaksanaan Inisiasi Menyusu Dini (IMD) Di Desa Sukaraya Kecamatan Pancur Batu Kabupaten Deli Serdang Tahun 2018. [SKRIPSI]. Politeknik Kesehatan Kemenkes RI Medan ; Medan

Badan Pusat Statistik. (2017). Provinsi Jawa Timur

Dewi, S. (2020). Konseling IMD. CV Media Sains Indonesia: Kota Bandung

Dwi, Djauhar, Dewi. (2016). Hubungan Tingkat Pengetahuan dengan Sikap Ibu Hamil tentang Inisiasi Menyusu Dini di Puskesmas Jetis Kota Yogyakarta. STIKES 'Aisyiyah Yoyakarta; Yogyakarta

Gerakan ASI Ekslusif. (2006). Gerakan ASI Eksklusif. http://www.ekologi.litban g.depkes.go.id/gerakanas ieksklusif.html, diakses pada 3 November 2014.
Infodatin. (2018). Menyusui sebagai Dasar Kehidupan: Pusat Data dan Informasi Kementrian Kesehatan RI.

Indah, Fanny. (2012). Gambaran Karakteristik Ibu yang Melakukan Inisiasi Menyusu Dini Di BPS "S" Kulon Progo 2012

Kementerian Kesehatan RI. (2019). Profil Kesehatan Indonesia. Kementerian Kesehatan RI. Jakarta.

Khasanah, N. 2013. ASI atau Susu Formula Ya?. FlashBooks. Yogjakarta.

Khoniasari, A. (2015) 'Pengaruh Paritas, Pengetahuan Ibu, Dukungan Keluarga, Dan Peran Tenaga Kesehatan Terhadap Pelaksanaan Inisiasi Menyusu Dini Di Rsud Salatiga

Manuaba, I.B.G. (2008). Gawat Darurat Obstetri Ginekologo \& Obstetri Ginekologi Sosial Untuk profesi Bidan. Jakarta : EGC.

Maritalia, D. (2014) Asuhan Kebidanan Nifas dan Menyusui. Yogyakarta: Pustaka Pelajar.

Nidya , A. (2018). Faktor-Faktor Yang Berhubungan Dengan Inisiasi Menyusu Dini Di Wilayah Kerja Puskesmas Satelit Bandar Lampung: Jurnal Kesehatan Panca Bhakti Lampung 
Notoatmodjo, S. (2007). Promosi Kesehatan dan Ilmu Perilaku. Jakarta: Rineka Cipta.

. (2012). Pendidikan dan Perilaku Kesehatan. Jakarta: Rineka Cipta

Nursalam.(2016). Konsep dan Penerapan Metodologi Penelitian Ilmu Keperawatan. (Edisi 2). Jakarta: Salemba Medika

Prakoso, H. (2002). Penggunaan ASI dan Rawat Gabung Dalam Ilmu Kebidanan, Jakarta: Yayasan Bina Pustaka Sarwono Prawirohardjo.

Prasetyono, D. S. (2012). Buku Pintar ASI Eksklusif. Yogyakarta: DIV A Press

Prawirohardjo, Sarwono. (2007). Ilmu Kebidanan, Edisi Ketiga Cetakan Ke Sembilan. Jakarta: YBP-SP .(2016). Ilmu Kebidanan, Yayasan Bina Pustaka Sarwono Prawirohardjo, Jakarta.

Soetjiningsih. (2011). ASI Petunjuk Untuk Tenaga Kesehatan. Jakarta : EGC.

Utami Roesli. (2008). Inisiasi Menyusu Dini Plus ASI Eksklusif. Jakarta : Pustaka Bunda

.(2012). Panduan Inisiasi Menyusu Dini plus ASI
Eksklusif, Pustaka Bunda, Jakarta

Varney, H. (2006). Buku Ajar Asuhan Kebidanan Vol 2. Jakarta : EGC. 